\title{
Mil razones para seguir adelante
}

\author{
Blanca Judith Lavoignet Acosta
}

\section{Resumen}

La pandemia por el virus SARS-CoV-2 ha ocasionado grandes estragos en todos los contextos, incluyendo el de la educación, lo que ha afectado a los protagonistas (docentes y estudiantes) del proceso de enseñanza-aprendizaje, de manera holística. En está ocasión sólo conoceremos a uno de ellos.

Palabras clave: educación, salud, familia, reflexión.

\section{ONE THOUSAND REASONS TO KEEP GOING}

\begin{abstract}
The SARS-COV-2 virus pandemic has caused great damage at all contexts, including education, which has affected the protagonists (teachers and students) of the teaching-learning process, in a holistic way. In this occasion we will only explore one of them.
\end{abstract}

Keywords: education health, family, reflection. 
"Mil razones para seguir adelante"

Blanca Judith Lavoignet Acosta

Vol. 22, Núm. 1, enero-febrero 2021

Revista Digital Universitaria

\section{Blanca Judith Lavoignet Acosta}

lavoignet_23@hotmail.com

orcid.org/0000-0001-9501-5392

Docente de Tiempo Completo categoría C, perfil PRoDEp. Funciones sustantivas: docencia, gestión, tutoría y producción académica-científica.

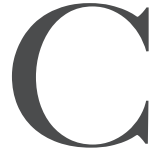

uando la vida decidió hacer una pausa, me di cuenta de que muchas cosas iban a cambiar, pero no vislumbre la magnitud, las consecuencias que eso acarrearía a mi vida laboral, personal, social-familiar y de salud. Yo soy docente de una facultad de enfermería. En el mes de marzo del año en curso, nuestras autoridades universitarias, en concordancia con lo emitido por las autoridades sanitarias, tomaron la decisión de seguir con las actividades de manera virtual y a distancia. Ante este panorama, tuve que modificar mis actividades académicas de un momento a otro, principalmente las de docencia, a otra modalidad. Para mí fue un enorme cambio. De encontrarme durante varios años en un aula de clases frente a mis estudiantes, pasé a estar en un proceso de enseñanza-aprendizaje a través de redes sociales, correos electrónicos, telefonía móvil, en fin, mediante la tecnología en general. El cambio no fue por el hecho de no haber utilizado esos medios, sino que ahora sería un 100\% de dedicación a ellos.

De manera autónoma tuve que capacitarme en la utilización de plataformas virtuales educativas y otros recursos que desconocía. Sobre todo me preocupaba y me sigue preocupando que el área de salud implica un acompañamiento cercano del docente con el estudiante. He tratado de hacer uso de todos los medios a mi alcance para seguir brindándoles a mis estudiantes esa guía, esa asesoría, la conducción que ellos necesitan para poder comprender con mayor claridad los temas de las asignaturas que imparto. 
"Mil razones para seguir adelante"

Blanca Judith Lavoignet Acosta

Vol. 22, Núm. 1, enero-febrero 2021

Revista Digital Universitaria

En el período escolar pasado utilicé el correo electrónico, Facebook, Skype, y plataformas como Eminus, Zoom. En este ciclo, incorporé el uso de la plataforma Teams, que realmente me ha funcionado, pues brinda más ventajas que desventajas en comparación con otras plataformas. ¡Vaya que el uso de la tecnología ha tenido un gran impacto en mi formación, en mi labor como docente! Al inicio fue algo frustrante, pero ahora me defiendo con más herramientas.

Todo lo anterior ha implicado desajustes en mi vida integral: el hecho de pasar varias horas sentadas frente a una computadora y el no poder salir frecuentemente fuera de estas cuatro paredes han afectado mi salud. Estoy presentando dolores frecuentes de cabeza, cansancio en ojos, dolores musculares, especialmente de espalda y nuca. Lo que más preocupa es la tensión en la que me encuentro debido a las exigencias laborales. Y es que el hecho de estar en casa no implica que no existan actividades que realizar: clases, atención a tutorados, exámenes, revisar tantos y tantos trabajos - yo tengo a mi cargo 5 grupos que van entre 40 y 35 estudiantes por grupo-. De igual manera, está la exposición a la que uno se enfrenta al estar frente a una computadora, comisiones de otras índoles, etcétera.

Todo ello ha ocasionado que me encuentre en un constante estrés y ansiedad. He llegado a tener momentos de mucho cansancio, desesperación, a sufrir insomnio porque mi cabeza no deja de trabajar. He sentido tanto dolor en el cuerpo que me he puesto a llorar de una manera desconsolada; a veces quisiera poder dormir un día y una noche completas, y, aunado a esto, está la preocupación de que alguien de mi familia pudiera enfermar, sobre todo mi compañero de vida, quien es enfermero y todos los días sale a trabajar. Cada mañana le pido a Dios y a la Virgen que lo protejan. He tenido también, en este tiempo, perdidas muy significativas de personas valiosas en mi vida, de las que, por la situación que estamos atravesando, no he podido despedirme como quisiera, y eso ha traído consigo dolor.

Sin embargo, he reflexionado que no soy la única que está pasando por malos momentos: desafortunadamente hay personas que están viviendo peores situaciones y que están saliendo adelante. ¿¿Por qué yo no podría?! Doy gracias a Dios que sigo conservando mi trabajo, cuando tantas personas lo han perdido; que no tengo que salir a exponerme, cuando muchos por necesidad lo tienen que hacer; que mis seres queridos más cercanos, mi familia, mi esposo, mis amigas, se encuentran bien; que yo estoy bien dentro de lo cabe; que lo que me ocurre se puede controlar; que cuando necesite platicar con alguien de cómo me siento sólo tengo que hacer una llamada y alguien estará ahí para escucharme.

Agradezco que Dios, la vida, no sé, me siguen permitiendo respirar un día más y disfrutar de lo que está a mi alcance, cuando muchos ya no pueden hacerlo. Si te sientes solo, recuerda que no es así. Aunque suene trillado, siempre hay alguien que está para ti, pero a veces no lo tenemos presente. Sobre todo, 
olvidamos que nos tenemos a nosotros mismos y que debemos querernos. Aprendamos a valorar lo que tenemos y hasta lo que hemos perdido, porque es algo que también se nos olvida con frecuencia. Disfrutemos de cada instante, porque cada día es diferente. Pero, sobre todas las cosas, amémonos para que podamos amar a los demás, cuidémonos y cuidemos a los demás. La vida hizo una pausa, pero hay mil razones para seguir adelante.

\section{Cómo CITAR ESTE ARTículo}

* Lavoignet Acosta, Blanca Judith. (2021, enero-febrero). Mil razones para seguir adelante. Revista Digital Universitaria (RDU), 22(1). Dol: http://doi.org/10.22201/ cuaieed.16076079e.2021.22.1.13 